Jahangirnagar University J. Biol. Sci. 4(1): 19-25, 2015 (June)

\title{
Ichthyodiversity of the Bangshi river, Savar, Dhaka
}

\author{
Md. Kamrujjaman* and Md. Rafiqun Nabi \\ Department of Zoology, Jahangirnagar University, Savar, Dhaka-1342, Bangladesh
}

\begin{abstract}
Fish diversity of Bangshi river, Savar, Dhaka was studied over a period of two consecutive years (July, 2010 to June, 2012). A total of 48 fish species belonging to 39 genera, 18 families and 8 orders were recorded. Siluriformes was the most dominant order comprising $33.33 \%$ of all the number of species recorded, followed by the Cypriniformes (31.25\%), Perciformes (14.58\%), Clupiformes (6.25\%), Channiformes (6.25\%), Osteoglossiformes (4.16\%), Synbranchiformes $(2.08 \%)$ and Beloniformes $(2.08 \%)$. The most dominated species of this study were Ailia punctata, Mystus tengra and Puntius sophore and rare species was Bagarius yarrellii. During the study 29 sp. $(40.42 \%)$ fish species were found to be locally rare, whereas, only $3 \mathrm{sp} .(6.25 \%)$ were very common and $16 \mathrm{sp}$. (33.33\%) were common in occurrence. Among the fishes, $52.08 \%$ was threatened in which vulnerable, endangered and critically endangered were $20 \%, 36 \%$ and $44 \%$ respectively.
\end{abstract}

Key words: Fish diversity, Bangshi river, Dhaka

\section{INTRODUCTION}

Fish biodiversity of a river essentially represents the fish faunal status and their abundance. River conserves and supports comparatively varieties of fish species which in turn supports commercial fishery. Once upon a time, rivers of Bangladesh were rich in fish diversity but, gradually number of fishes was decreasing toward threatened status. According to a report of the International Union for Conservation of Nature (IUCN) in 2000 , Bangladesh was a home of 266 freshwater fish species of which, 54 were classified as "threatened" and grouped under the 'Red List' species. Bangladesh being rapidly developing country of the south-east Asia, currently holds 1176 industries that discharge about 0.4 millions $\mathrm{m}^{3}$ of untreated wastes either directly or indirectly in to the rivers in a day (Rabbani \& Sharif, 2005). This increasing industrialization and consequent agricultural revolution have already brought negative impact on the water quality (BCAS, 2004). The Bangshi river, located at Savar of Dhaka district is one of the important rivers in central Bangladesh. Once, the river was the prime habitat for many diversified fresh water fishes. But, now it lost all of the riverine characters including its fish resources. The thing becomes more worsen with the industrial effluents mainly from Dhaka Export Processing Zone (DEPZ) as well as river grabbing, siltation and many more anthropogenic factors. Therefore, present research was aimed to carry out to obtain present status of fish diversity in the Banghsi river, Savar, Dhaka.

\section{MATERIALS AND METHODS}

Fish samples were collected and recorded from June to October over a period of two consecutive years from July, 2010 to June, 2012. For this research, four sampling sites

\footnotetext{
*Corresponding author. E-mail: monir_zoo@yahoo.com
} 
namely, St. $1\left(23^{\circ} 55^{\prime} 32^{\prime \prime} \mathrm{N}, 090^{\circ} 13^{\prime} 32 \mathrm{E}\right)$, St. $2\left(23^{\circ} 54^{\prime} 35^{\prime \prime} \mathrm{N}\right.$ and $\left.090^{\circ} 13^{\prime} 51 \mathrm{E}\right)$, St. 3 $\left(23^{\circ} 53^{\prime} 45^{\prime \prime} \mathrm{N}\right.$ and $\left.090^{\circ} 13^{\prime} 56 \mathrm{E}\right)$ and St. $4\left(23^{\circ} 52^{\prime} 54^{\prime \prime} \mathrm{N}\right.$ and $\left.090^{\circ} 13^{\prime} 59 \mathrm{E}\right)$ were selected for getting almost complete record about the available fish species (Fig.1). From each of these sampling sites, fishes were harvested by local fisherman using different types of nets namely, gill nets, cast nets, lift net (dharma jal) and dragnets were collected. As soon as a new fish species was found, photographs were taken and then preserved in 8$10 \%$ formaldehyde. The fishes were brought to the laboratory and preserved finally with fresh formaldehyde in separate jars. Smaller fishes were directly placed in the formalin solution while, larger fishes were given an incision and labeled properly on the abdomen before they were fixed. Identification was done based on keys used by Bhuiyan (1964), Talwar \& Jhingaran (1991), Shafi \& Quddus (2001), Rahman (2005) and finally recorded in the museum of the Department of Zoology, Jahangirnagar University.

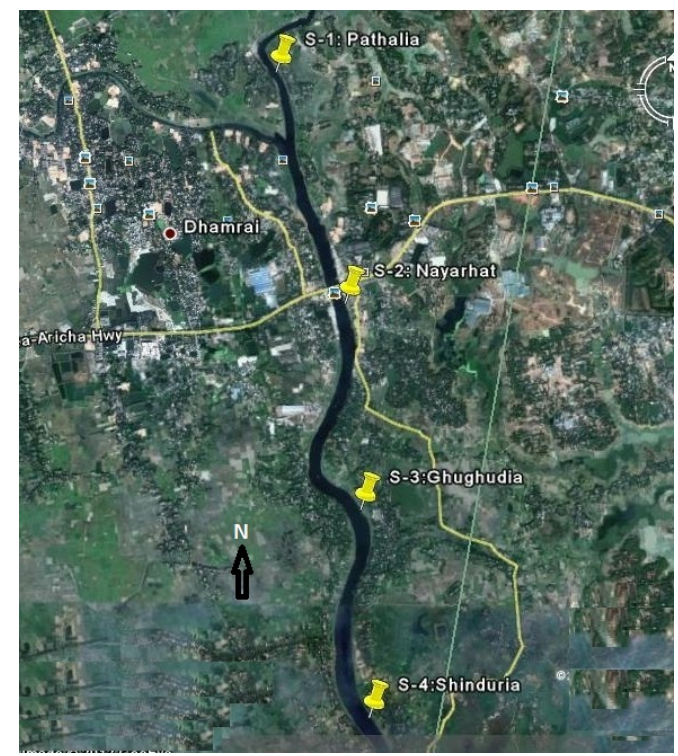

Fig. 1. Satellite image of the Bangshi river, Savar, Dhaka, showing the four sampling sites

All collected data were then used to calculate "Relative Abundance" of a particular fish species" by following the method of Jadhav et al. (2011) with slight modification i.e., the relative abundance of the fish was classified into three categories namely Very common (67-100\%), Common (34-66\%), and Rare (1-33\%) on the basis of their availability in total catch. Consequently, the statuses of recorded fishes were determined following IUCN Bangladesh (2000).

\section{RESULTS AND DISCUSSION}

A total of 48 species of fresh water fishes belonging to 39 genera, 18 families and 8 orders were recorded (Table 1). 
Table 1. Fish species recorded from the Banghi river during July 2010 to June 2012

\begin{tabular}{|c|c|c|c|c|c|c|}
\hline Order & Family & Species & Common name & Local name & $\begin{array}{c}\text { Relative } \\
\text { abundance }\end{array}$ & Status \\
\hline \multirow[t]{2}{*}{ Osteoglossiformes } & Notopteridae & Notopterus chitala & Humped Featherback & Chital & + & EN \\
\hline & & Notopterus notopterus & Grey Featherback & Foli & ++ & VU \\
\hline \multirow[t]{3}{*}{ Clupiformes } & Clupeidae & Gonialosa manmina & Ganges river Gizzard Shad & Chapila & ++ & NO \\
\hline & & Anodontosoma chacunda & Chacunda Gizzard-shad & Koi puti & + & NO \\
\hline & & Corica soborna & Gang River sprat & Kachki & + & NO \\
\hline \multirow[t]{3}{*}{ Channiformes } & Channidae & Channa marulius & Giant snakehead & Gajar & + & EN \\
\hline & & Channa punctatus & Spotted Snakehead & Taki & + & NO \\
\hline & & Channa striatus & Striped Snakehead & Shol & ++ & NO \\
\hline \multirow{15}{*}{ Cypriniformes } & Cobitidae & Lepidocephalus guntea & Guntea Loach & Gutum & ++ & NO \\
\hline & & Botia dorio & Nechtie Loach & Rani & + & EN \\
\hline & Cyprinidae & Amblypharyngodon mola & Pale Carplet & Mola & + & NO \\
\hline & & Salmostoma acinaces & Silver Razorbelly Minnow & Chela & + & DD \\
\hline & & Catla catla & Catla & Katla & + & NO \\
\hline & & Cirrhinus mrigala & Mrigal & Mrigel & + & NO \\
\hline & & Labeo bata & Bata Labeo & Bata & + & EN \\
\hline & & Cirrhinus reba & Reba carp & Tatkini & + & VU \\
\hline & & Danio devario & Devario danio & Bashpata & ++ & NO \\
\hline & & Labeo calbasu & kalbaus & kalibasu & ++ & EN \\
\hline & & Labeo rohita & Rohu & Rui & + & NO \\
\hline & & Osteobrama cotio & Coti & Dhela & + & EN \\
\hline & & Puntius ticto & Ticto Barb & Tit Punti & + & VU \\
\hline & & Puntius sophore & Spotfin Swamp Barb & vadi punti & +++ & NO \\
\hline & & Barilius tileo & Tileo Baril & Patharchata & + & DD \\
\hline \multirow[t]{10}{*}{ Siluriformes } & Pangasiidae & Pangasius pangasius & Pungas & Pungus & + & $\mathrm{CR}$ \\
\hline & Plotosidae & Plotosus canius & Canine Catfish-eel & Gang-Magur & + & VU \\
\hline & Schilbeidae & Clupisoma garua & Garua Bacha & Ghaura & ++ & $\mathrm{CR}$ \\
\hline & & Eutropiichthys vacha & Batchwa Bacha & Bacha & + & $\mathrm{CR}$ \\
\hline & & Silonia silondia & Silondia & Shillong & + & EN \\
\hline & & Ailia punctata & Jamuna Ailia & kajuli & +++ & VU \\
\hline & Siluridae & Ompok pabda & Pabdah catfish & Pabda & + & EN \\
\hline & & Wallago attu & Freshwater shark & Boal & ++ & NO \\
\hline & & Bagarius yarrellii & Gangetic Goonch & Baghair & ++ & $\mathrm{CR}$ \\
\hline & & Glypothorax telchitta & Copper catfish & Teli/Telchitta & + & DD \\
\hline
\end{tabular}


Cont.

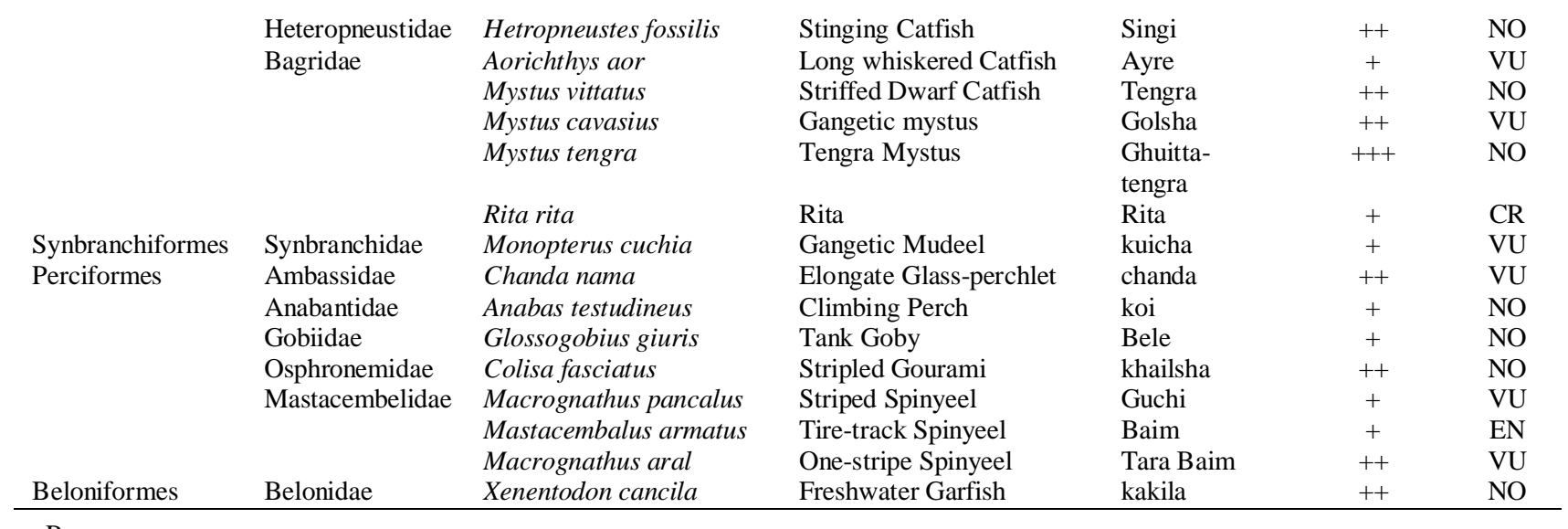

+=Rare, ++=common, +++=very common,

$\mathrm{CR}=$ Critically Endangered, EN= Endangered, VU- Vulnerable, LR- Lower Risk, NO- Not Threatened, DD- Data Deficient 
However, there is no previous study on fish fauna of the Bangshi river, but, obviously it seems very poor condition compared to other rivers in Bangladesh. Hossain \& Haque (2005), Mohsin \& Haque (2009), Joardder (2009), De at al. (2011), Rahman et al. (2012), Galib et al. (2013), Flowra et al. (2013), Alam et al. (2013), Paul et al. (2014) and Mohshin et al. (2014) reported 135 species under 33 families, 56 species under 20 families, 78 species under 19 families, 59 fin fishes under 19 families, 80 species under 24 families, 63 species under 23 families, 60 species under 20 families, 63 species under 24 families, and 53 species under 28 families from the river Padma, Mahananda, Atrai, Bangali, Padma, Choto Jamuna, Baral, Halda, and the Andharmanik river respectively. The only variation found in Titas river was 35 species of fish (Ahmed \& Akter, 2008), which is fewer than the present findings in the Banghsi river.

The percentage distribution of fish species under respective orders suggest that the Siluriformes was the most dominant order comprising $33.33 \%$ of all the number of species recorded followed by the Cypriniformes (31.25\%), Perciformes (14.58\%), Clupiformes (6.25\%), Channiformes (6.25\%), Osteoglossiformes (4.16\%), Synbranchiformes and Beloniformes of each $2.08 \%$ (Fig. 2). On the otherhand, among the recorded 18 families, Siluriformes comprises 6 families followed by Perciformes (5), Cypriniformes (2), Clupiformes, Channiformes, Osteoglossiformes, Synbranchiformes and Beloniformes of each containing 1 family and their relative percentage were $33.33 \%$, $27.77 \%, 11.11 \%, 5.55 \%, 5.55 \%, 5.55 \%, 5.55 \%$ and $5.55 \%$ respectively. whereas, Joarder (2009), Rahman et al. (2012), Galib et al. (2013), Flowra et al. (2013), Alam et al. (2013) reported Cypriniformes most dominated order as followed by Siluriformes and perciformes in the Atrai, Padma, Choto Jamuna, Baral and Halda river respectively. But, Moshin \& Haque (2009) recorded Siluriformes as a dominated family followed by Cypriniformes and Perciformes in the Mahananda river and Mohshin et al. (2014) reported Perciformes followed by Siluriformes and Cypriniformes in the Andharmanik river.

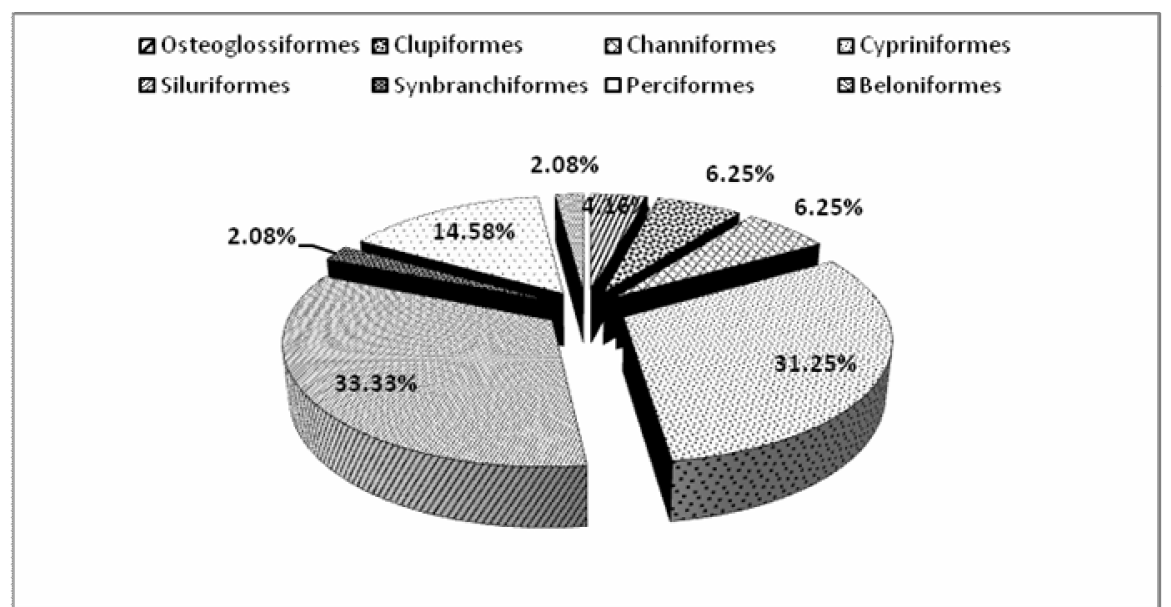

Fig. 2. Percentage of species composition under different orders recorded in the Bangshi river during July 2010 to June 2012 
Among the fishes, the representative of family Cyprinidae was most dominant and 13 species of fishes were recorded under this family. The number of species recorded under the family Bagridae were 5, Schilbeidae and Siluridae were 4, Clupeidae, Chanidae and Mastacembelidae were 3, Notopteridae and Cobitidae were 2, and Pangasiidae, Plotosidae, Heteropneustidae, Synbranchidae, Ambassidae, Anabantidae, Gobiidae, Osphronemidae and Belonidae were 1. The highest number of fish species under the family Cyprinidae might be due to congenial river bottom which they prefer most. Similar observation was also reported by Mohshin \& Haque (2009), De et al. (2011), Joadder (2012), Rahman et al. (2012), Alam et. al. (2013), Galib et al. (2013), Flowra et al. (2013) in the Mahananda, Bangali, Atrai, Padma, Halda, Choto Jamuna, Baral river, respectively, whereas, Mohshin et al. (2014) reported Clupeidae as a dominated family in the Andhermanik river.

Again, among the identified fishes, Ailia punctata, Mystus tengra and Puntius sophore were dominated species while, Bagarius yarrellii was rare species. Among the recorded fishes, maximum $29(60.42 \%)$ species were rare, whereas, only $3(6.25 \%)$ were very common and $16(33.33 \%)$ were common. Among the recorded 48 species of fish, 25 (52.08\%) were threatened. Again, among the threatened fish species Vulnerable, Endangered, Critically Endangered species were 05 (20\%), 09 (36\%) and 11 (44\%), respectively (Fig. 3). However, abundance of 52.08\% threatened species among the total recorded fish species reflecting its potentiality to be an excellent site for natural conservation. The comparatively low species diversity and abundance suggested the presence of stress-inducing factors in this river.

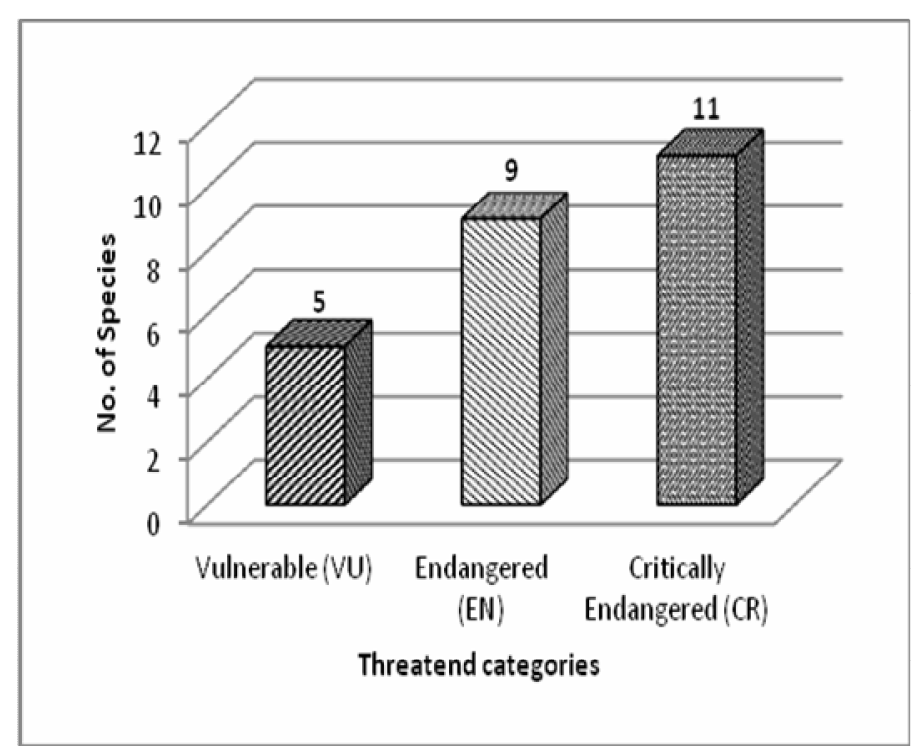

Fig. 3. Status of recorded threatened fish species in the Bangshi river during July 2010 to June 2012 


\section{REFERENCES}

Ahmed, M.D.S. and Akther, H. 2008. Brush and Vegetation Park Fishery in the River Titas, Brahmanbaria, Bangladesh. South Pacific Studies. 29(1): 63-71.

Alam, M.S., Hossain, M.S. Monwar, M.M., Hogue, M.E. and Taimur, F.M. 2013. Check-list of bony fish collected from the Upper Halda River, Chittagong, Bangladesh. AACL Bioflux. 6(4): 333-338.

BCAS (Bangladesh Centre for Advanced Studies). 2004. The state of Bangladeshi water, vol. V. Bangladesh Centre for Advanced Studies, Dhaka, Bangladesh,pp. 42-49.

Bhuiyan, A.L. 1964. Fishes of Dacca. Asiatic society of Pakistan, Dacca, pp. 148.

De, M., Hussain, M.A., Alam, M.M., Mazlan, A.G., and Simon, K.D. 2011. Impact of Sariakandi fish pass on fisheries diversity of Bangali river, Bogra, Bangladesh. AACL Bioflux. 4(5): 621-626.

Flowra, F.A., Islam, M.A., Jahan, S.N., Hussain, M.A., Alam, M.M., Bashir, F.A., Mazlan, A.G., and, Simon, K.D. (2013). Status and decline causes of fish diversity of Baral River, Natore, Bangladesh. AACL Bioflux 6(4): 352-357.

Galib, S.M., Naser, S.M.A., Mohsin, A.B.M., Chaki, N. and Fahad, F.H. 2013. Fish diversity of the River Choto Jamuna, Bangladesh: Present status and conservation needs. International Journal of Biodiversity and Conservation. 5(6): 389-385.

Hossain, M.A. and Haque M.A. 2005. Fish species composition in the river padma near Rajshahi. J Life Earth Science. 1(1): 35-42.

IUCN 2000. Red Book of Threatended Fishes of Bangladesh, International Union for Conservation of Nature, Dhaka, pp.57-78.

Jadhav, B.V., Kharat, S.S., Raut, R.N., Paingankar, M. and Dahanukar, N. 2011 Freshwater fish fauna of Koyna River, northern Western Ghats. India Journal of Threatened Taxa. 3(1): 1449-1455.

Joadder, A.R. 2009. A Comprehensive Study on the Availability of Fishes and Non-Fin Fishes in Atrai River of Naogaon District: A Case Study in Northern Part of Bangladesh. Journal of Fisheries International. 4(2):19-22.

Mohshin, A.B.M. and Haque, E. 2009. Diversity of Fishes of Mahananda river at Chapai Nawabgonj district. 2009. Res. J. Bio. Sci. 4(7): 828-831.

Mohsin, A.B.M. Yeasmin, F. Galib, S.M., Alam, B. and Haque, S.M.M. 2014. Fish Fauna of the Andharmanik River in Patuakhali, Bangladesh. Middle-East Journal of Scientific Research. 21(5): 802-807.

Paul, B., Faruque, M. and Ahsan, D.A. 2014. Consequences of climate change on fish biodiversity in the river Turag, Bangladesh: A community perception study. World J. Fish and Marine Sci. 6(2): 136-141.

Rabbani, G. and Sharif, M.I. 2005. Dhaka City- state of Environment (SoE) 2005. UNEP in collaboration with BCAS and DoE, pp.40.

Rahman, A.K.A. 2005. Freshwater fishes of Bangladesh, $2^{\text {nd }}$ edn., The Zoological Society of Bangladesh, Department of Zoology, University of Dhaka, Dhaka, pp. 485.

Rahman, M.M., Hossain, Y.M., Ahamed, F., Fatematuzzhura, Subba, B.R., Abdallah, E.M. and Ohtomi, J. 2012. Biodiversity in the Padma Distributary of the Ganges River, Northwestern Bangladesh: Recommendations for Conservation. World Journal of Zoology. 7 (4): 328-337.

Shafi, M. and Quddus, M.M.A. 2001. Bangladesher matshaw sampad (Bangla). Kabir Publications, Dhaka, pp.485.

Talwar, P.K. and Jhingaran A. 1991. Inland fishes of India and adjacent countries, vol. I \& II Oxford and IBH Publishing Co. New Delhi, pp. 1158115-6. 